\title{
УПРАВЛЕНИЕ КОНФЛИКТАМИ
}

А.В. Манойло

DOI: 10.7256/2305-560X.2013.3.6221

\section{УПРАВЛЕНИЕ ПСИХОЛОГИЧЕСКОЙ ВОЙНОЙ}

Аннотация. В статье сформулированы две основные концепции реализации государственной политики в условиях психологической войны - противодействие психологической войне и управление психологической войной. Концепция управления психологической войной - деятельность по изменению системных свойств войны в избранном направлении при помощи инструментов внешнего политического воздействия - базируется на принципе, что, если что-то нельзя победить, то его нужно организовать и возглавить. Применение этой концепции на практике позволяет государственной политике достигать цели, недостижимые для концепции противодействия, и в корне меняет устоявшиеся представления о показателях и степени опасности современной информационно-психологической войны. По нашему мнению, в системе государственной информационной политики именно управление информационно-психологической войной станет в ближайшем будущем важнейшей категорией деятельности органов власти в особых условиях.

Ключевые слова: политология, международные отношения, внешняя политика, национальная безопасность, психологическая война, информационная война, психологические операции, управление, конфликт, США.

\section{1. Формат вооруженных конфликтов нового поколения}

C егодня внимание всей научной общественности приковано к событиям, которые развиваются в Афганистане, Пакистане, Ираке, на Ближнем Востоке и в Северной Африке, в Египте, Ливии, Сирии. Ирак в это отношении является показательным примером, скоторого все началось. Сейчас уже достаточно очевидно, что Ирак рассматривался американским командованием как идеальный полигон для испытания новых средств и способов ведения войны, и, в первую очередь, для отработки в режиме реальных боевых действий новых тактических концепций и технологий информационно-психологического воздействия. В политическом плане важность того, что происходило в Ираке, трудно недооценить: именно благодаря успешности избранной силами вторжения тактики ведения боевых действий страна не только была полностью взята под контроль (или оккупирована - как кому нравится), но и появилась возможность строить планы принудительного возвращения в русло американской политики таких давних оппонентов как Иран и КНДР. В научном плане многие ученые не перестают отмечать, что американо-иракский вооруженный конфликт развивался совершенно иначе, чем его предшественники, и, если анализировать его чисто в военном плане, то многие действия американского командования не просто непонятны, но иногда кажутся нелогичными, примитивными, не учиты- вающими местной специфики. Для внешних наблюдателей, следивших за конфликтом с экранов телевизоров, странное «топтание» коалиционных сил вблизи Басры и сложные маневры бронетанковых колонн вокруг незначительных иракских портовых городков дали повод говорить о том, что американцы либо ввязались в конфликт, не имея четких планов подавления иракской обороны ${ }^{1}$, либо столкнулись с неожиданно сильным сопротивлением, к которому не были готовы. Когда же активные действия коалиционных сил временно замирали, это, как правило, объяснялось стремлением командования союзников избежать потерь. Однако, эти потери все равно возникали, и нередко в тот самый момент, когда общественность, замершая у экранов телевизоров, начинала скучать, наблюдая, как обладающие огромной ударной поражающей мощью элитные войска союзников безуспешно пытаются выбить иракских стрелков из трех-четырех занимаемых ими сараев. При этом боевые потери армии США в Ираке мгновенно собирали у экранов телевизоров огромную аудиторию американских граждан и, затем, фокусировали их внимание на тех ма-

\footnotetext{
1 В свое время очень популярной была такая версия причин возникновения конфликта: Буш-младший пришел в Ирак чтобы отомстить за Буша старшего, потому что давно мечтал об этом. И как только такая возможность представилась, он тут же развернул военную машину США для подготовки вторжения. А на осторожные замечания генералитета о том, что иракская компания может дорого обойтись, он, вероятно, ответил что-то вроде: «Когда речь идет о чести семьи, разговор о деньгах неуместен».
} 


\section{Международные отношения International Relations}

териалах, которые подавались сразу после сводок с фронтов.

Если рассматривать версию об относительно слабой первоначальной готовности армии США к ведению боевых действий в Ираке, то, с нашей точки зрения это, конечно, не так - если бы американские войска приступили бы к покорению Ирака без заранее продуманного плана, вряд ли им это бы удалось с такими минимальными потерями и в такие короткие сроки. С точки зрения бизнеса, иракская операция была исключительно успешной формой реализации коммерческого проекта - за короткий срок административный контроль над огромной территорией перешел в руки союзного командования, которое теперь свободно распоряжается уцелевшей экономикой покоренной страны и богатейшими нефтяными месторождениями. Это позволяет сделать вывод, что ни одно из действий американского командования не было случайным просто перед нами, внешними наблюдателями, разыгрывался хорошо срежиссированный спектакль, рассчитанный на то, чтобы держать в постоянном напряжении аудиторию, управляя ее эмоциями в интересах реализации собственной государственной политики. Действительно, в течение нескольких месяцев миллионы зрителей по всему земному шару заворожено следили за многосерийными сводками боевых действий в Ираке, который по своей популярности вытеснил даже знаменитые «мыльные оперы». При этом мало кто замечал, что ударные группировки союзников как будто позируют перед телекамерами, и в боевые действия вступают только тогда, когда уже заранее известен их пиар-эффект. Ничего лишнего, ни одного движения, не попавшего в кадр. Создается впечатление, что иракские бойцы в спектакле играют роль массовки, которую «экономно расходуют» так, чтобы хватило на следующие серии. Сам же сценарий компании строится так, чтобы обеспечить информационнопсихологическое воздействие на американскую и международную общественность - аудиторию, следящую за войной с экранов телевизоров, - с целью обеспечения ее добровольного подчинения. Такой сценарий, по сути, есть новая разновидность технологий информационно-психологического воздействия на сознание, в котором с реальностью работают так, как это делают с сюжетом журналистского репортажа. При этом собственно боевые действия становятся одной из сцен, предусмотренных сценарием, и теряют свою ключевую, самостоятельную, роль.

С нашей точки зрения, наблюдая с экранов телевизоров за «странной» войной в Ираке, мир уви- дел появление войн нового поколения - информационно-психологических, в которых собственно боевые действия играют подчиненную сервисную роль, а план вооруженной кампании строится по правилам и в соответствии со сценарием пиар-воздействия на собственных граждан, на граждан политических союзников и оппонентов и на международное сообщество в целом. Таким образом, мы можем со всеми основаниями говорить о том, что современный вооруженный конфликт развивается в жанре репортажа и по законам этого жанра, с тем чтобы генерируемые им новости своим форматом максимально близко соответствовали формату пиар-материала, необходимого для реализации технологий информационно-психологического воздействия. В результате такая цепочка производства (боевыми подразделениями вооруженных сил) и практической реализации (силами психологических операций) новостей с театра военных действий становится высокотехнологичным конвейером производства инструментов обработки и формирования общественного мнения, обеспечения добровольного подчинения, политического целеуказания и управления вектором политической активности элит, находящихся у власти в различных странах. Продукт современной операции информационно-психологической войны - это сводка новостей СМИ в формате журналистского репортажа.

Сегодня информационно-психологические войны нового поколения становятся эффективным инструментом внешней политики: пусть общество не обманывает то, что в репортажах с театра военных действий зрители видят, что жертвы агрессии не они сами, а граждане Ирака в далекой стране, положение которой на карте далеко не все укажут с первого раза. Цель любой информационно-психологической операции - добровольная подчиняемость общества, которая обеспечивается при помощи технологий психологического воздействия на сознание его граждан. Пиар-компания, сопровождающая военные действия в Ираке, тому явное подтверждение - формат и характер вещания рассчитаны, в основном, на граждан тех стран, которые в той или иной степени негативно относятся к политическому курсу администрации США, при этом в преподносимых зрителям материалах несложно выявить типично манипулятивные приемы работы с информацией. Это позволяет говорить о том, что в информационно-психологической войне, ведущейся в Ираке, под прицелом находятся не только граждане этой страны, но и мы сами. 


\section{Управление конфликтами / Conflict management}

\section{2. Информационное противоборство и информационно-психологическая война - к вопросу о соотношении понятий}

Сам термин «информационно-психологическая война» был перенесен на российскую почву из словаря военных кругов США. Дословный перевод этого термина («information and psychological warfire») с родного для него языка - английского - может звучать и как «информационное противоборство», и как «информационная, психологическая война», в зависимости от контекста конкретного официального документа или научной публикации. Многозначность перевода данного термина на русский язык почему-то стала причиной разделения современных российских ученых на два соперничающих лагеря - на сторонников «информационного противоборства» и сторонников «информационной войны», несмотря на то, что, на языке оригинала это, по существу, одно и то же. Вводя в употребление термин «информационно-психологическая война», американские ученые, как гражданские, так и военные, придерживаются традиционной для американской культуры прагматичной идеологии, ориентированной не столько на конкретные сиюминутные нужды, сколько на ближайшую перспективу: используя термин «информационная война», они формируют в сознании властных кругов и общественности в целом целевую установку на то, что в будущем эта форма отношений станет настолько развитой и эффективной, что полностью вытеснит традиционное вооруженное противостояние. Да, говорят американцы, мы уже настолько хорошо изучили психологию человека и научились ею управлять, что для обеспечения его безусловной подчиняемости нам уже не нужно применять грубую силу - армию и полицию. Те же способы подчинения могут быть применены и к любой социальной системе. Если же социальная система не желает добровольно подчиняться, мы заставим ее это сделать с помощью современных комплексных технологий тайного информационно-психологического воздействия, причем для непокорной социальной системы результат такого противостояния будет равносилен поражению в войне.

По нашему мнению, у американцев информационная война используется не столько как термин, обозначающий современную фазу развития конфликтных социально-политических отношений, сколько как вектор формирования внешней политики, как программа выбора политического курса и конечная цель эволюции инструментов политического управления. Поэтому, непрекращающиеся сегодня баталии российских ученых по поводу того, правомерно ли называть современные информационно-политические конфликты информационными войнами или все-таки лучше использовать для этого термин «информационное противоборство», на наш взгляд, не приведут к существенным для науки результатам.

Не секрет, что современная концепция информационно-психологических войн США основана на трудах и практическом опыте стратагемной политики китайских военных и политических деятелей, таких как выдающийся полководец и государственный деятель Сунь-Цзы ${ }^{2}$, живший в IV в. до н.э. в древнекитайском царстве Ци. Можно предположить, что, если бы, например, концепция информационных войн пришла бы в российскую политику и науку непосредственно из Китая, то, возможно, мы бы сейчас спорили о том, не является ли информационно-психологическая война всего лишь очередной фазой эволюции азиатской политической мысли, в которой традиционно почитаемая на востоке хитрость и коварство переплетаются в сложнейшей сети явных и тайных политических интриг. И наверняка бы возник вопрос: можно ли острый политический конфликт называть информационно-психологической войной, если даже в те времена, когда основные ее положения уже были сформулированы (IV в. до н.э.), традиционное военное искусство не только не потеряло своего значения, но и начало активно развиваться именно в направлении массированного применения грубой вооруженной силы. То есть, если тогда, на зачаточной стадии развития военного искусства, не произошло вытеснение новыми формами психологической борьбы более примитивных и архаичных форм прямой вооруженной агрессии, то почему это должно произойти сейчас, при современном уровне развития систем вооружений и военного искусства в целом?

Определяя информационное противоборство как наиболее общую категорию социальных отношений, мы придерживаемся следующей точки зрения: к информационному противоборству можно отнести любые формы социальной и политической конкуренции, в которых для достижения конкурентного преимущества предпочтение отдается средствам и способам информационно-психологического воздействия. Видно, что понятие информационного противоборства включает в себя весь спектр конфликтных ситуаций в информационно-психологической сфере - от межличностных

\footnotetext{
Конрад Н.И. Сунь-цзы. Трактат о военном искусстве. М.Л., 1959.
} 


\section{Международные отношения International Relations}

конфликтов до открытого противостояния социальных систем. Информационно-психологическая война - это, безусловно, также один из видов информационного противоборства.

Почему же возникла необходимость введения нового термина «информационно-психологическая война»? И с чем связана такая его живучесть? Ведь, где бы этот термин не употреблялся, все прекрасно понимают, о чем идет речь. Именно это определяет практическую ценность данного термина в системе научных знаний. По нашему мнению, существует несколько основных причин, благодаря которым этот, вообще говоря, публицистический, термин так прочно вошел в научные труды и нормативные документы:

- во-первых, использование термина «информационно-психологическая война» применительно к сфере вооруженного противоборства подчеркивает все возрастающую роль психологических операций в современных войнах и локальных вооруженных конфликтах: современные войны все более становятся психологическими, напоминающими масштабную PR-кампанию, a собственно военные операции постепенно оттесняются на второй план и играют четко определенную и ограниченную роль, отведенную им в общем сценарии военной кампании;

- во-вторых, использование данного термина подчеркивает, что современные технологии психологической войны способны нанести противнику не меньший ущерб, чем средства вооруженного нападения, а информационное оружие, построенное на базе технологий психологического воздействия, обладает значительно большей поражающей, проникающей и избирательной способностью, чем современные системы высокоточного оружия;

- в-третьих, использование данного термина подчеркивает ту роль, которую начинают играть информационно-психологические операции в международной политике, вытесняя из политической практики или замещая в ней иные, боле традиционные, формы политического регулирования, такие как война вообще и военные акции, в частности;

- в-четвертых, применение данного термина вызвано необходимостью подчеркнуть высокую социальную опасность некоторых современных организационных форм и технологий информационно-психологического воздействия, используемых в политических целях.

С нашей точки зрения, наиболее корректно понятие информационно-психологической войны описывает определение: ИПВ - это политический конфликт по поводу власти и осуществления политического руководства, в котором политическая борьба происходит в форме информационно-психологических операций с применением информационного оружия $[4,12]$.

\section{3. Правомерно ли использовать термин "война» при описании агрессивных форм информационно-психологической борьбы?}

Но все это, конечно, лишь наиболее общие рассуждения о том, почему термин «информационнопсихологическая война» так прочно прикрепился к ряду явлений современной политической жизни. Истинная же причина этого, на наш взгляд, состоит в том, что современная агрессивная информационно-психологическая борьба сама порождает локальные войны и вооруженные конфликты, которые становятся индикатором информационно-психологической войны, ее «витриной» и основной формой политического проявления скрытых процессов, лежащих в ее основе. При этом в современной информационно-психологической войне вооруженные конфликты играют строго отведенную им роль.

Для того, чтобы запустить, или инициализировать, тот или иной боевой механизм информационно-психологического воздействия на сознание (или подсознание), необходим мощный толчок, или стресс, способный вывести от природы устойчивую систему психики человека из равновесного состояния и активизировать в ней поиск новых защитных механизмов, адекватных стрессовой ситуации ${ }^{3}$. В качестве такой защиты психотехнологи любезно готовы предложить свою идеологию, мировоззрение, систему ценностей, замещающие в человеке прежние психологические механизмы защиты. Что, в конечном итоге, обеспечивает достижение главной цели любой современной психологической операции добровольную подчиняемость личности.

Такой эффект на психику человека способна оказать только внезапно возникшая угроза для его жизни: неизвестная медицине эпидемия (например, атипичная пневмония), стихийное бедствие ... или война. При этом, если наступление первых двух событий предсказать достаточно сложно ${ }^{4}$, то войну

\footnotetext{
3 Для этого, кстати, не обязательно, чтобы угроза, вытекающая из стрессовой ситуации, была реальной - достаточно создать иллюзию того, что в изменившейся ситуации прежние механизмы психологической защиты уже не работают, либо не справляются с возлагаемой на них нагрузкой.

4 и поэтому они принципиально не подходят в качестве инициирующего толчка для планирования операций психологиче-
} 
или локальный вооруженный конфликт можно породить практически в любой точке земного шара и в тот самый момент, когда это предусмотрено сценарием психологической операции ${ }^{5}$. Кроме того, угроза войны - идеальный инициирующий повод для психологического стресса: угроза войны одновременно направлена и на крупные страты (государства, нации, народности), и непосредственно на каждую личность в отдельности.

Таким образом, на современной стадии развития политических технологий информационнопсихологическая война не всегда начинается собственно с военных действий, но сами военные действия становятся необходимым фактором любой боевой психологической операции - в качестве средства инициирования ${ }^{6}$ цепных психологических реакций, предусмотренных сценарием психологической войны. Война психологическая порождает

ской войны. Так называемая эпидемия атипичной пневмонии, не является исключением из этого правила: такие эпидемии возникают регулярно (в частности, вирус гриппа мутирует каждый год) и их просто не замечают. Сам миф о смертельно опасной эпидемии атипичной пневмонии был сформирован искусственно, и, безусловно, является одной из составляющих информационно-психологической операции США в Ираке, но цель его - отвлечь мировое общественное мнение от неудач союзных сил в войне - является примером того, как грамотно и оперативно в психологической войне могут быть использованы любые изменения оперативной обстановки.

5 Не случайно на примере войны в Ираке (1992-1994 г.) мы видим, что современная война напоминает масштабный пиар-спектакль, в котором делается только то, что попадает в кадр кинокамер в соответствии с пиар-сценарием кампании, а кровь своих солдат, солдат противника и союзных сил льется только в тех случаях, когда это необходимо для достижения пиар-эффекта.

6 В свете этих положений, как представляется, становятся понятны некоторые «нелогичные» эпизоды войны в Ираке например, странное бездействие союзных сил в Басре и ряде других населенных пунктов, когда мощная военная машина наступающих войск неожиданно забуксовала и остановилась при первых звуках выстрелов иракских ополченцев, которые, по определению, не могли ни задержать вторжение, ни даже нанести ему ощутимый урон. Тем не менее, войска союзников остановились и вели себя пассивно, если не сказать - сонно, в течение нескольких недель, становясь темой для пересудов, политических сплетен, слухов и официальных заявлений. Не ставя под сомнение профессионализм американских и британских военных, хочется заметить, что, вполне возможно, во всех указанных случаях сам штурм и оккупация населенных пунктов не был главной целью для войск вторжения - своей активизацией, сопровождающейся потерями как среди своих, так и среди чужих, американо-британские части в течение месяца подбрасывали для мировой общественности шокирующие пиар-уколы, выполняющие роль инициализирующего механизма для запуска сценария очередного этапа психологической операции. Т.е., возможно, быстрый и бескровный штурм Басры изначально не был в планах союзных войск. войну локальную: для перехода психологической операции из латентной стадии в активную необходим инициирующий повод, а, следовательно, нужен локальный вооруженный конфликт. То, что в планах информационно-психологической войны традиционная война играет ограниченную, строго отведенную ей роль, не делает ее менее опасной, не сокращает ее масштабов и не вытесняет ее из сферы политических отношений - глобальные военные конфликты постепенно исчезают из политической жизни (в условиях ИПВ в них больше нет необходимости), количество же локальных вооруженных конфликтов и частота их возникновения растет.

Наблюдающийся сегодня постепенный перенос политической борьбы в информационно-психологическую сферу увеличивает риск возникновения локальных вооруженных конфликтов: технологии информационно-психологической войны многим кажутся привлекательными именно в силу их относительной дешевизны, доступности и эффективности, а, следовательно, интенсивность их использования в политической борьбе будет только нарастать. Соответственно, будет увеличиваться и количество локальных вооруженных конфликтов, которые в психологических операциях играют роль инициирующего механизма - «спускового крючка». Что, в конечном итоге, ведет к распространению практики применения собственно вооруженного насилия: там, где начинается психологическая война, обязательно возникнет локальный вооруженный конфликт.

Таким образом, психологическая война - это и есть боевые действия, спланированные в соответствии с пиар-сценарием, цель которых - не уничтожение живой силы и техники противника, а достижение пиар-эффекта.

\section{4. Базовый принцип противодействия операциям психологической войны}

Продукт современной операции информационно-психологической войны - это сводка новостей СМИ в формате журналистского репортажа. Соответственно, продукт информационно-психологической контроперации - сводка новостей, которая делает построение такого репортажа неудачным.

\section{5. Методика исследования психологической войны}

Сегодня информационно-психологическая война как фактор внешней политики исследуется наравне с дипломатической, экономической и вооруженной борьбой, развиваясь вместе с тем как само- 


\section{Международные отношения International Relations}

стоятельное направление научного исследования. Однако, по нашему мнению, ни один из существующих сегодня научных подходов не раскрывает сущность информационно-психологической войны ни как политического конфликта, ни как социального явления, что, возможно, и является основной причиной неэффективности выбираемых сегодня средств и методов политического регулирования данной категории общественных отношений. Все это требует разработки новой методологии исследования информационно-психологической войны, которая позволяла бы, в зависимости от конкретной политической ситуации, рассматривать это явление в глобальных масштабах, на геостратегическом, тактическом и прикладном уровне.

С нашей точки зрения, информационно-психологическая война (ИПВ) в рамках научного исследования может рассматриваться на различных уровнях познания:

- как социальное явление;

- как поле политических конфликтов;

- $\quad$ как особая форма политического конфликта;

- как элемент системы инструментов политического регулирования (инструмент информационной политики).

В рамках каждого из указанных уровней рассмотрения информационно-психологическая война исследуется в рамках собственной научной гипотезы:

1. Социологическая гипотеза информационнопсихологической войны: информационно-психологическая война - социальное явление и новая форма общественных отношений, порождаемая информационным обществом.

2. Статистическая гипотеза информационно-психологической войны: информационно-психологическая война - поле политических конфликтов, находящихся в тесной взаимосвязи и взаимодействии;

3. Конфликтологическая гипотеза информационно-психологической войны: информационнопсихологическая война - политический конфликт с целью разрешения противоречий по поводу власти и управления, в котором столкновение сторон осуществляется в форме информационно-психологических операций с применением информационного оружия [1].

Цель информационно-психологической войны: разрешение противоречий по поводу власти и осуществления политического руководства в информационно-психологическом пространстве.

Задачи информационно-психологической войны:
- трансформация структуры национальных экономических, политических, социально-культурных, информационно-психологических пространств участников международных отношений в соответствии с собственными принципами формирования информационно-политической картины мира;

- достижение военно-политического превосходства и безусловного лидерства в сфере международных отношений;

- достижение целей национальной экономической, идеологической, культурной, информационно-психологической экспансии;

- обеспечение благоприятных условий для перехода собственной национальной системы социально-политических отношений на новый, более высокоразвитый и высокотехнологичный этап эволюционного развития.

Признаки информационно-психологической войны:

- насилие как основная форма взаимодействия участников информационно-политического конфликта;

- информационно-психологические операции как специальная организационная форма оказания политического воздействия на участников конфликта;

- применение информационного оружия.

4. Системно-функциональная гипотеза информационно-психологической войны: информационно-психологическая война - часть системы политического регулирования, инструмент информационной политики.

В рамках социологической гипотезы информационно-психологическая война рассматривается как новая форма социальных отношений (объект социологического анализа), а спектр конфликтных ситуаций, порождаемыхпсихологической войной, как внешнее проявление системных свойств данного объекта.

В рамках статистической гипотезы информационно-психологическая война рассматривается как сложная высокодифференцированная система (поле) политических конфликтов, находящихся в тесной взаимосвязи и взаимодействии, каждый из которых рассматривается как единичная реализация ансамбля конфликтных ситуаций, генерируемых или проявляемых полем психологической войны.

В рамках конфликтологической гипотезы информационно-психологическая война рассматривается как политический конфликт, имеющий самостоятельное значение как объект исследования и управления, находящийся во взаимодействии и 


\section{Управление конфликтами / Conflict management}

взаимообусловленности с другими политическими конфликтами.

В рамках системно-функциональной гипотезы информационно-психологическая война рассматривается как часть системы информационной политики как агрессора, так и жертвы агрессии, в рамках которой информационно-политические конфликты, порождаемые психологической войной, интегрируются в структуру политической системы конфликтующих сторон и используются ими в качестве инструментов политического регулирования [2].

Разумеется, правомерность применения каждой гипотезы к понятию информационно-психологической войны требует доказательства.

Теорема 1. Информационно-психологическая война - социальное явление.

Доказательство: информационно-психологическая война - это форма насилия, в которой в качестве инструмента принуждения используются возможности воздействия информации на психику человека. Можно выделить два основных признака социальности этого явления:

- применение насилия в качестве основной формы воздействия;

- использование возможностей воздействия информации на психику человека в качестве инструмента социального принуждения.

Насилие в социальных отношениях - явление достаточно распространенное, чтобы считать его социальным: насилие невозможно без общественной организации и социально-политической иерархии, системы подчинения одних членов общества другим. При применении насилия предпочтение всегда отдается тем средствам, способам и инструментам социального принуждения, которые в условиях данной общественной организации наиболее эффективны. В информационном обществе такими инструментами являются комплексные организационные технологии информационно-психологического воздействия.

Теорема 2. Информационно-психологическая война - политический конфликт. Доказательство: Информационно-психологическая война обладает следующими признаками политического конфликта:

- имеет место столкновение конфликтующих сторон, которое последовательно проходит основные стадии развития социального конфликта: предконфликтную ситуацию (нарастание социальной напряженности или формирование конфликта характеризуется осознанием несовместимости интересов и позиций, консолидацией сторон конфликта; выдвижением требований к оппоненту), латентную, инцидент, эскалацию, сбалансированное противодействие, кульминацию и угасание (разрешение противоречий или преобразование в иную форму).

- также как и социальный конфликт, информационно-психологическая война проходит через следующие фазы: конфронтационную (военную), в которой стороны стремятся обеспечить свой интерес за счет устранения чужого; компромиссную (политическую), в которой стороны стремятся по возможности достичь своего интереса через переговоры, в ходе которых производят замену отличающихся интересов каждого субъекта на общий, компромиссный; коммуникативную (управленческую), в которой стороны стремятся достичь согласия в том, что суверенитетом обладает не только каждый субъект конфликта, но и его интерес и ликвидируют лишь незаконные с точки зрения сообщества различия в процессе движения к взаимодополнению интересов;

- информационно-психологические войны возникают всегда по поводу перераспределения власти и осуществления политического руководства в обществе.

Соответствие этим признакам позволяет отнести информационно-психологическую войну к категории политических конфликтов.

Теорема 3. Информационно-психологическая война - поле политических конфликтов и статистическая система.

Доказательство: Информационно-психологическая война как часть системы политических отношений - это совокупность всех политических конфликтов, в которых предпочтение отдается различным видам информационно-психологического насилия, принимающего специальную организационную форму тайных операций с обязательным использованием информационного оружия. Современная наука (в силу непознанности данного политического явления) еще не позволяет описать всю систему информационно-политических конфликтов в ее динамике и развитии в аналитической форме (т.е. в форме многопараметрической функции или функционала), но, в принципе, разрешает рассматривать множество конфликтов как некое политическое пространство с заданными свойствами, определяющими характер взаимодействия материи и элементов этого пространства с любыми политическими явлениями и процессами, не принадлежащими ему, - т.е. позволяет рассматривать информационно-психологическую войну как поле политических конфликтов 


\section{Международные отношения International Relations}

и обосновывает правомерность использования формализма и понятийного аппарата теории поля к описанию данного явления.

Множественность и многообразие форм и проявлений информационно-политических конфликтов позволяет рассматривать поле конфликтов как статистическую систему, в которой многофакторное взаимодействие, взаимозависимость и взаимообусловленность множества элементов порождает общие закономерности поведения и трансформации структуры конфликтной материи на уровне законов больших чисел.

Теорема 4. Информационно-психологическая война - часть системы политического регулирования, инструмент информационной политики.

Доказательство: Информационно-психологическая война - часть системы:

- политического регулирования, поскольку ее цель - разрешение противоречий по поводу власти и осуществления политического руководства в информационно-психологическом пространстве;

- информационной политики, поскольку для агрессора война - средство (инструмент) достижения политических целей, для жертвы агрессии - средство (инструмент) нанесения ответного удара и восстановления военно-политического баланса.

Сформулированные выше гипотезы не исключают и не дублируют, а взаимодополняют друг друга, позволяя исследовать информационно-психологическую войну как сложное, многогранное явление в жизни общества, по своим масштабам выходящее за рамки рассмотрения какой-либо одной научной дисциплины [5-9]. В самом деле, в основу иерархии гипотез положен принцип детализации объекта научного исследования:

- рассматривая информационно-психологическую войну с позиций социологического подхода, мы видим объективное и целостное социальное явление, значимость которого можно определить только в сравнении с другими социальными явлениями подобного масштаба;

- рассматривая его более детально, мы, в первом приближении, видим, что материя данного объекта исследования соткана из множества информационно-политических конфликтов, взаимосвязанных, взаимообусловленных и взаимодействующих между собой. Огромное разнообразие форм и проявлений этих конфликтов не позволяет наблюдателю, стремящемуся держать в поле зрения их все или какую-то их заметную часть, определить, является ли по- павший в поле зрения конфликт тем самым, который был наблюдаем им ранее, или это уже другой конфликт, развитие которого привело к появлению признаков и качеств, наблюдавшихся ранее у первоначально наблюдаемого конфликта (эргодичность поля политических конфликтов). Проблема идентификации наблюдателем информационно-политических конфликтов, имеющих большой период латентного развития, в условиях их множественной генерации и затухания, позволяет вводить в аппарат исследователя понятие поля политических конфликтов, и, используя формализм теории поля, исследовать наиболее общие закономерности поведения конфликтной материи, возникающие в результате множественного многофакторного взаимодействия большого количества разноуровневых политических конфликтов.

- отказавшись от цели держать в поле зрения сразу достаточно большую часть поля политических конфликтов, мы ограничиваемся в рамках конфликтологической гипотезы рассмотрением отдельно-взятого информационно-политического конфликта и его эволюции во времени и пространстве. Таким образом, еще более приблизившись к объекту наблюдения информационно-психологической войне - мы уже не видим все многообразие его внутренней структуры, но, зато, в состоянии выделить из нее отдельные элементы - информационнополитические конфликты - и исследовать их индивидуальные свойства. Для этой цели хорошо приспособлен аппарат современной политической конфликтологии.

- $\quad$ и, наконец, исследование психологической войны как информационно-политического конфликта позволяет выделить те ее структурные свойства и элементы, которые могут быть интегрированы в систему информационной политики, т.е. стать, как минимум, - управляемыми, а, как максимум, - выполнять в этой системе определенные функции, в том числе - функции инструмента политического регулирования. Таким образом, информационно-психологическая война исследуется на этом (системно-функциональном) уровне уже не как самостоятельный политический объект, а как структурный элемент, деталь более сложного политического объекта - системы информационной политики.

Такая градация уровней детального рассмотрения информационно-психологической войны предполагает применение следующих методов исследования: 
- социологических (при исследовании ИПВ как социального явления);

- статистических (при исследовании ИПВ как поля политических конфликтов);

- политической конфликтологии и политической психологии (при исследовании ИПВ как формы политического конфликта);

- логико-структурного и системно-функционального анализа (при исследовании ИПВ как часть системы и инструмента информационной политики).

\section{6. Социальные функции психологической войны}

Исследование информационно-психологической войны как социального явления позволяет выделить две основные социальные функции информационно-психологической войны: деструктивную и регулирующую.

Деструктивная функция состоит в том, что информационно-психологическая война приводит к долговременным изменениям в системе социальнополитических отношений общества, к перестройке ее структуры, прямых и обратных связей с учетом появления новых, практически нерегулируемых нормами права, форм политического экстремизма; к обострению политической борьбы и распространению практики применения прямых форм насилия в политических целях. Применение современных технологий информационно-психологической войны приводит к поражению центральной нервной системы человека, выражающееся в разрушении индивидуального сознания, изменении или разрушении системы ценностей, нанесении ущерба психическому здоровью, изменении или частичной утрате способности к абстрактно-логическому мышлению, что в долгосрочной перспективе сказывается на генофонде нации. Негативное воздействие на сознание и психику личности не прекращается даже после устранения источника агрессии.

Регулирующая функция состоит в разрешении противоречий по поводу власти и осуществления политического руководства в информационно-психологическом пространстве методами, исключающими необходимость применения прямой вооруженной агрессии. В современном обществе информационно-психологическая война замещает и вытесняет эту форму конфликтных взаимоотношений в политической борьбе. В международных отношениях наблюдается тенденция использования поражающего потенциала современной информационно-психологической войны в целях сдерживания прямой вооруженной агрессии - т.н. информационно-психологическое сдерживание (аналог сдерживания военного), подразумевающее управление кризисными ситуациями с помощью превентивных акций по информационно-психологическому воздействию на население и властные структуры в зонах возможного возникновения конфликтов.

Регулирование уровня социальной опасности информационно-психологической войны как средства жесткого политического принуждения и формы неконтролируемого насилия не может сводиться только к введению системы запретов и ограничений: информационно-психологическая война базируется на использовании в основе своих технологий скрытого воздействия тех же базовых элементов и способов социальной коммуникации, что и другие социальные процессы и, как социальное явление и разновидность социального конфликта, не может быть искоренена, но может удерживаться на определенном, контролируемом обществом уровне социальной опасности.

\section{7. Государственная информационная политика}

Центральное место в регулировании социальной опасности информационно-психологической войны занимает государственная информационная политика. Однако, современная государственная информационная политика России не в состоянии защитить российское общество от разрушительного воздействия информационно-психологической войны в связи с низкой готовностью российского общества оказывать активное сопротивление любым попыткам манипулирования общественным сознанием. В то время как в массовом сознании граждан еще только формируется понимание той угрозы, которую могут нести современные информационно-психологические войны, технологии информационно-психологической войны уже воздействуют не только на сознание, но и на подсознание.

В условиях информационно-психологических войн возникает необходимость изменения концепции существующей государственной информационной политики в целях ее адаптации к новым условиям, и в предположении, что, как постоянное социальное явление, информационно-психологическую войну на данном этапе развития общества искоренить нельзя, но можно удерживать на определенном, контролируемом обществом уровне социальной опасности с помощью государственного регулирования.

Недостаточная эффективность существующей государственной информационной политики в условиях информационно-психологической войны: 


\section{Международные отношения International Relations}

- $\quad$ требует изменения всей концепции действующей информационной политики в целях ее адаптации к современных условиям, в которых происходит формирование информационного общества;

- позволяет говорить об особых условиях ее реализации и необходимости выработки специальных методов и механизмов политического воздействия, адекватных тем революционным изменениям, которые сегодня происходят с системой социально-политических отношений современного общества.

В условиях информационно-психологической войны задача формирования государственной информационной политики должна состоять в поиске закономерностей, принципов, форм и методов политического регулирования, позволяющих:

- подготовить общество к активному противодействию информационно-психологической войне;

- противодействовать информационно-психологической войне на государственном уровне с активным участием институтов гражданского общества;

- осуществлять целеполагание, формирование организационной структуры, методическое и ресурсное обеспечение системы государственного управления по критериям: опережающего развития по сравнению с системой осуществления информационно-психологической агрессии (войны); адекватности противостояния информационно-психологической войне как постоянному социальному явлению (конфликту).

В условиях информационно-психологической войны возникают новые тенденции и закономерности реализации государственной информационной политики:

1.1. Социальная адаптация информационнопсихологической войны: эволюция информационно-психологической войны в направлении усиления ее регулирующей социальной функции способна преобразовать информационно-психологическую войну в один из институтов регулирования информационно-политических отношений.

Государственная информационная политика в дальнейшем будет основываться на усилении регулирующей социальной функции информационно-психологической войны и ослаблению ее деструктивной функциисцелью превращенияагрессивнойформы информационно-политических отношений - войны в один из институтов регулирования общественных отношений.

1.2. Социальная редукция конфликтогенного потенциала информационно-психологической во- йны: формирование институтов информационного общества, обеспечивающее опережающее развитие системы информационно-политических отношений гражданского общества по отношению к существующим формам и методам информационнопсихологической войны, приводит к редукции ее конфликтогенного потенциала.

Государственная информационная политика в будущем откажется от курса на поиск и устранение объективных противоречий, порождающих информационно-политические конфликты, и будет концентрировать силы на формировании институтов информационного общества.

1.3. Объектно-субъектный дуализм политических конфликтов в системе информационной политики: в системе информационной политики политические конфликты выступают одновременно и как объект информационного управления, и как основной инструмент управления другими политическими конфликтами и процессами.

Информационная политика в дальнейшем будет использовать информационно-политические конфликты как инструмент информационного управления другими политическими конфликтами и процессами. В рамках этой концепции множественность и многообразие институциональных политических конфликтов, выполняющих роль инструментов информационного управления, определяет гибкость, многовариатность и эффективность информационной политики.

1.4. Институализация внешней информационно-психологической агрессии: информационнопсихологическая война, распознанная системой информационно-психологических отношений объекта агрессии на ранних стадиях, становится институциональным конфликтом, а распознанная на последующих стадиях - объектом управления информационной политики.

Государственная информационная политика в дальнейшем будет содействовать интенсивному развитию и проявлению мероприятий информационно-психологической войны на ранних стадиях (воздействуя на активность источников агрессии) и управлять ими - на последующих стадиях.

В условиях информационно-психологической войны появляются новые сущностные черты государственной информационной политики:

- как постоянное социальное явление, информационно-психологическую войну на данном этапе развития общества искоренить нельзя, но можно удерживать на определенном, контролируемом обществом уровне социальной опасности. В открытом гражданском обществе 


\section{Управление конфликтами / Conflict management}

единственная возможность установления государственного контроля над этим явлением состоит в управлении информационно-психологической войной как объектом управления с целью редукции его системных свойств и статуса до уровня институционального конфликта;

- информационно-психологическая война использует объективные противоречия политической системы общества в качестве объекта управления. Государственная информационная политика, способствуя формированию информационного общества, тем самым обеспечивает опережающее развитие системы информационно-политических отношений гражданского общества по отношению к существующим формам и методам информационно-психологической войны, устраняя или видоизменяя скрытые противоречия, на управлении которыми война основывается;

- информационная политика позволяет выявить истинные, глубинные противоречия в развитии общества, лежащие в психологии социальных отношений, рассматривая возмущения политического поля (классические политические конфликты) не как прямое проявление, а как индикатор существования таких противоречий.

\section{8. Концепции психологической войны: принцип противодействия и принцип управления}

В условиях психологической войны основная функция государственной информационной политики - защита общества от негативного информационно-психологического воздействия - включает в себя две основные составляющие:

- противодействие информационно-психологической войне;

- управление информационно-психологической войной.

Концепция противодействия предполагает, что:

- во-первых, информационно-психологическая война - внешний фактор по отношению к защищаемой системе и мы не можем повлиять на причины возникновения этого явления, поскольку это происходит где-то за пределами защищаемой системы;

- во-вторых, противодействуя войне, мы вмешиваемся в закономерности формирования и развития данного информационно-политического конфликта, нарушаем нормальные темпы его эволюции и изменяем условия перехода от одной фазы развития конфликта к другой. В принципе, такое вмешательство может нару- шить течение психологической войны как политического конфликта и привести даже к ее политической дезорганизации.

- в-третьих, каждый новый информационнополитический конфликт представляет собой новую угрозу для защищаемой системы. Чем больше возникает новых конфликтов, тем больше угроз.

Основной недостаток концепции противодействия состоит в том, что цель противодействия устранение или локализация информационно-политического конфликта в том месте, где он возник, в условиях множественности информационно-политических конфликтов становится недостижима: вступая в борьбу с информационно-политическими конфликтами, мы боремся с частными проявлениями нового социального явления - психологической войны, - но не с самим явлением.

Концепция управления психологической войной в информационной политике базируется на принципе, что, если что-то нельзя победить, то его нужно организовать и возглавить. Управление информационно-психологической войной - деятельность по изменению системных свойств войны в избранном направлении при помощи инструментов внешнего политического воздействия. По нашему мнению, в системе государственной информационной политики именно управление информационно-психологической войной является важнейшей категорией деятельности органов власти в особых условиях.

Концепция управления психологической войной позволяет достигать цели, недоступные для концепции противодействия: если войной можно управлять, то уже не так принципиально важно для общественной стабильности, много в политическом поле общества таких конфликтов или мало. Ведь, как только подобный конфликт где-то возникает, он тут же становится субъектом государственного регулирования, а, значит, начинает выполнять в обществе определенную социальную функцию. При всей своей агрессивности, конструктивные социальные функции у современной информационнопсихологической войны все-таки есть: это, в первую очередь, вытеснение из поля международных отношений традиционных форм вооруженной борьбы и т.н. информационное сдерживание. Использование этих функций психологической войны в системе международных отношений (в сочетании с подавлением ее деструктивных составляющих) позволяет рассматривать психологическую войну даже как инструмент информационной политики. Кроме того, управление информационно-политическими конфликтами в принципе не может быть эффективно, 


\section{Международные отношения International Relations}

если конфликтов мало - в условиях единичности конфликтов каждый конфликт начинает вести себя индивидуально и так или иначе выходит за рамки общих статистических тенденций и закономерностей, на которых построено информационное управление. Следовательно, множественность конфликтов в концепции управления психологической войной не препятствие, а основное условие эффективности применения такой концепции на практике.

Если рассматривать концепцию управления психологической войной в рамках социологической, статистической, конфликтологической и системно-функциональной гипотез, то мы получим следующую картину.

В системе государственной информационной политики можно выделить различные уровни управления информационно-психологической войной:

1. Управление психологической войной как социальным явлением:

регулирование социальной опасности психологической войны;

- усиление конструктивной социальной функции психологической войны и редукция ее деструктивной социальной функции (социальная адаптация);

- социальная редукция конфликтогенного потенциала психологической войны.
2. Управление полем информационно-психологических войн как полем политических конфликтов (статистической системой):

- управление конфликтогенным потенциалом;

- управление векторным потенциалом психологической агрессии;

- управление векторной функцией психологической агрессии (изменение направления вектора психологической агрессии или его компенсация);

3. Управление психологической войной как разновидностью политического конфликта:

- управление восприятием (на уровне личности);

- управление коммуникацией (на уровне отдельных личностей, групп, стратов);

- управление групповой сплоченностью (на уровне групп);

- управление динамикой конфликта;

- редукция статуса и системных свойств информационно-психологической войны до уровня институционального конфликта;

- дезорганизация политического конфликта;

- институализация психологической агрессии.

4. Управление информационно-психологической войной как внутренним элементом системы информационной политики, использование психологической войны как инструмента внешнего и внутреннего политического регулирования.

\section{Источники:}

1. Манойло А.В., Петренко А.И., Фролов Д.Б. Государственная информационная политика в условиях информационно-психологической войны. - М.: Горячая линия - Телеком, 2003. - 541 с.: ил.

2. Манойло А.В. Государственная информационная политика в особых условиях, монография. - М.: Изд. МИФИ, 2003. - 388 с.: ил. (Cryptography.ru: http://www.cryptography.ru/db/msg.html?mid=1169716).

3. Манойло А.В. Информационное противоборство в условиях психологической войны. - М.: Закон и праBo. - 2003. — №12. - С. 31-34.

4. Manoïlo A.V. Gestion de la guerre psychologique dans le cadre de la politique informationnelle de l'Etat. P.: Politique et société. — №2'. - 2004.

5. PИA Iran News, Информационно-психологическая война: факторы, определяющие формат современного вооруженного конфликта (Андрей Манойло, 22.07 .05 11:33) http://www.iran.ru/rus/news_iran. php?act=news_by_id\&news_id=31796

6. Manoilo A.V., Psychological Warfare Management. - V.: Proceedings of The Forth International Scientific and Methodic Conference "IES-2004", 2004, pp. 375-378. (Intelligence to Business: http://it2b.biz/it2b2.view3. page19.html, Центр исследования компьютерной преступности: http://www.crime-research.org/articles/612/).

7. Директива МО США TS3600.I “Информационная война” от 21 декабря 1992 г.

8. Директива председателя КНШ МО США №30 «Борьба с системами управления», 1993 г.

9. Libicki M.C. What is Information Warfare? Washington, D.C. National Defense University Press, 1995; Stein G.H. Information Warfare // Airpower Journal. Spring 1995.

10. Szafranski R. A. Theory of Information Warfare: Preparing for 2020 // Airpower Journal. Spring 1995; Harley I.A. Role of Information Warfare. Truth and Myths. NTIS, Naval War College. AP-A307348. USA, 1996

11. Information Warfare, complex organisations and the power of disruption. University of Arisona, 1997

12. Information Warfare: Implications for Arms Control. Kings College London, ICSA. UK, 1998. 
13. Портал Министерства информационных технологий и связи РФ, Объекты и субъекты информационного противоборства: http://www.minsvyaz.ru/site.shtml?id=2503

14. Manoilo A.V. Research Problems of Forms and Methods of State Information-Psychological Warfare Regulation. V:: Proceedings of The Forth International Scientific and Methodic Conference "IES-2004", 2004, pp. 368-371

15. Manoilo A.V., Methods of Psychological Warfare Research. - V.: Proceedings of The Forth International Scientific and Methodic Conference "IES-2004", 2004, pp. 372-374. (http://it2b.biz/it2b2.view3.page18.html)

16. Манойло А.В. Информационно-психологическая война: факторы, определяющие формат современного вооруженного конфликта. - Киев: Материалы V Международной научно-практической конференции «Информационные технологии и безопасность». Вып. — №8. 2005. — С. 73-80.

17. Вепринцев В.Б., Манойло А.В., Петренко А.И., Фролов Д.Б. Операции информационно-психологической войны. Методы, средства, технологии: Краткий энциклопедический словарь-справочник. - М.: Горячая линия-Телеком, 2005. - 495 с.: ил.

18. Манойло А.В., Фролов Д.Б. Информационно-психологические операции как организационная форма реализации концепции информационно-психологической войны. СПб.: Проблемы информационной безопасности. Компьютерные системы. - 2003. — № 2. - С. 7-14.

19. Манойло А.В., Фролов Д.Б. Система социальных и политических отношений информационного общества как среда организации и проведения тайных операций информационно-психологической войны. СПб.: Проблемы информационной безопасности. Компьютерные системы. - 2003. - № 3. - С. 21-27.

\section{References (transliteration):}

1. Manoilo A.V., Petrenko A.I., Frolov D.B. Gosudarstvennaya informacionnaya politika v usloviyah informacionnopsihologicheskoi voiny. - M.: Goryachaya liniya - Telekom, 2003. — 541 s.: il.

2. Manoilo A.V. Gosudarstvennaya informacionnaya politika v osobyh usloviyah, monografiya. - M.: Izd. MIFI, 2003. - 388 s.: il. (Cryptography.ru: http://www.cryptography.ru/db/msg.html?mid=1169716)

3. Manoilo A.V. Informacionnoe protivoborstvo v usloviyah psihologicheskoi voiny. — M.: Zakon i pravo. — 2003. — №12. - S. 31-34.

4. RIA IranNews, Informacionno-psihologicheskaya voina: faktory, opredelyayushie format sovremennogo vooruzhennogo konflikta (Andrei Manoilo, 22.07.05 11:33) http://www.iran.ru/rus/news_iran.php?act=news_by_ id\&news_id=31796

5. Direktiva MO SShA TS3600.I "Informacionnaya voina" ot 21 dekabrya $1992 \mathrm{~g}$.

6. Direktiva predsedatelya KNSh MO SShA №30 «Bor'ba s sistemami upravleniya», 1993 g.

7. Portal Ministerstva informacionnyh tehnologii i svyazi RF, Ob'ekty i sub'ekty informacionnogo protivoborstva: http://www.minsvyaz.ru/site.shtml?id=2503

8. Manoilo A.V. Informacionno-psihologicheskaya voina: faktory, opredelyayushie format sovremennogo vooruzhennogo konflikta. - Kiev: Materialy V Mezhdunarodnoi nauchno-prakticheskoi konferencii «Informacionnye tehnologii i bezopasnost'». Vyp. — №8. 2005. — S. 73-80.

9. Veprincev V.B., Manoilo A.V., Petrenko A.I., Frolov D.B. Operacii informacionno-psihologicheskoi voiny. Metody, sredstva, tehnologii: Kratkii enciklopedicheskii slovar'-spravochnik. — M.: Goryachaya liniya-Telekom, 2005. 495 s.: il.

10. Manoilo A.V., Frolov D.B. Informacionno-psihologicheskie operacii kak organizacionnaya forma realizacii koncepcii informacionno-psihologicheskoi voiny. SPb.: Problemy informacionnoi bezopasnosti. Komp'yuternye sistemy. - 2003. - № 2. - S. 7-14.

11. Manoilo A.V., Frolov D.B. Sistema social'nyh i politicheskih otnoshenii informacionnogo obshestva kak sreda organizacii i provedeniya tainyh operacii informacionno-psihologicheskoi voiny. - SPb.: Problemy informacionnoi bezopasnosti. Komp’yuternye sistemy. — 2003. — № 3. — S. 21-27. 